Int. J. Electrochem. Sci., 11 (2016) $10362-10378$

\title{
Two-electrode Sensor System for Rapid Detection of Sulfonamides by Applying the Nafion-Carboxyl Multiwalled Carbon Nanotubes Powder Microelectrode
}

\author{
Baoshan $\mathrm{He}^{*}$, Wenbo Chen \\ School of Food Science and Technology, Henan University of Technology, Zhengzhou 450001, \\ People's Republic of China \\ *E-mail: hebaoshan@126.com
}

doi: $10.20964 / 2016.12 .63$

Received: 13 September 2016 / Accepted: 16 Ocober 2016 / Published: 10 November 2016

\begin{abstract}
A powder microelectrode (PME), embedded with Nafion-carboxyl multiwalled carbon nanotubes (MWCNTs), was prepared for selective and sensitive determination of sulfonamides. The effects of experimental parameters on the response of electrode such as $\mathrm{pH}$ of buffer, scan rate were optimized. Under optimal conditions, the proposed PME can greatly improve the determination sensitivity. In a Britton-Robison (BR) buffer solution ( $\mathrm{pH} 2.0$ ), the linear response range for detection of $1.0 \times 10^{-5}$ $\mathrm{mol} / \mathrm{L}$ to $1.0 \times 10^{-4} \mathrm{~mol} / \mathrm{L}$ of sulfonamide $\left(\mathrm{R}^{2}=0.984\right)$, sulfadiazine $\left(\mathrm{R}^{2}=0.993\right)$, sulfamethazine $\left(\mathrm{R}^{2}=0.987\right)$, sulfamethoxazole $\left(\mathrm{R}^{2}=0.982\right)$ and the detection limits of $2.69 \times 10^{-6} \mathrm{~mol} / \mathrm{L}, 3.10 \times 10^{-6}$ $\mathrm{mol} / \mathrm{L}, 8.94 \times 10^{-6} \mathrm{~mol} / \mathrm{L}$ and $5.79 \times 10^{-6} \mathrm{~mol} / \mathrm{L}$, respectively. The recoveries were in the range of $87 \sim 106 \%$ with RSD $<5 \%$ and the Nafion-MWCNTs PME performed excellent repeatability and durability. The proposed sensor was successfully applied for the determination of SAs in real samples and might offer feasibility and applicability for other determination of more complex sulfonamides compounds.
\end{abstract}

Keywords: Powder microelectrode; Nafion; Carboxyl; Multiwalled carbon nanotubes; Sulfonamides;

\section{$\underline{\text { FULL TEXT }}$}

(C) 2016 The Authors. Published by ESG (www.electrochemsci.org). This article is an open access article distributed under the terms and conditions of the Creative Commons Attribution license (http://creativecommons.org/licenses/by/4.0/). 